Fecha de recepción: abril 2018

Fecha de aceptación: noviembre 2018

Versión final: diciembre 2020

\section{Understanding how design processes can contribute to the enhancement of innovative capacity in the universe of startup companies}

\begin{abstract}
Innovation has been an important word in business in recent years. Associated with a number of highly profitable business models, gives entrepreneurs a challenge that goes beyond the definition of "promoting something new". Continuous innovation with positive results, relevant social impact and opportunities and balancing risks - is one of the great challenges of all sectors and dimensions. Encouraged by many examples of American success, globalization and post-industrialization, many young people ventured into the business world, developing content based on technology. Startups are one of these models, because they have unique characteristics when compared to traditional micro and small companies. Its condition of existence is innovation, however, however much a startup has a revolutionary idea, it is no guarantee of sustainable success.
\end{abstract}

Key words: Innovation - entrepreneurship - design management - startups - design.

[Abstracts in spanish and portuguese at pages 74-75]

${ }^{(*)}$ Isabela Moroni. Degree in Business Administration, a Master's and a $\mathrm{PhD}$ (in progress) in Design from the Federal University of Pernambuco ( Recife, Brazil). She is working in the Technology and Culture line of research and develops projects and papers in the BIODESIGN research laboratory. She is researcher in the areas of design management, strategic design, entrepreneurship, startups, innovation and creativity. She has published articles in national and international magazines and congresses on design and emphasizes the importance and practices in the corporate context and organizations and design. belamoroni@gmail.com

${ }^{(* *)}$ Amilton José Vieira de Arruda. He holds a degree in Industrial Design from UFPE (1982), a Master's degree in Design and Bionics from the Ricerche Center of the European Design Institute of Milan (1992) and a PhD in Industrial Design from Politecnico di Milan (2002). He has been an international consultant for the Milan Institute of Design in the implementation of lato sensu postgraduate courses at Ávila (Goiânia) and FBV (Recife) and at the Institute of Higher Education in Brasília (DF). Since 1985, he is professor of the UFPE Design course. Professor of the post graduate Program in Design at UFPE. Coordinator of the research group Biodesign and Industrial Artifacts of CNPp. Has experience in the area of strategic design with emphasis on design and bionics, biomimetics, acting on our topics: product development, graphic design, editorial and strategic design. Coordinator and editor with the publisher Blucher, of the [designCONTEXTO] series. arruda.amilton@gmail.com 


\section{Introduction}

From the period from the mid-eighteenth century to the present day, the society of consumption is contemplated by significant changes, thanks to the capacity of people to undertake. In the past, the increase in the supply of products has enabled society to access to meet its needs. This period of development and consolidation of capitalism was fundamental thanks to the entrepreneur's role. According to Timmons (1990) apud Dornelas (2008), "Entrepreneurship is a silent revolution, which will be for the 21 st century more than the Industrial Revolution was for the twentieth century". Emphasis in this context also characterizes the current society of consumption, which is called "the era of entrepreneurship".

The entrepreneur is given the possibility of shortening the distances of the world, the technological advance, the new working relations, the increase of the wealth through the generation of more jobs and the improvement of the quality of life of the people. It is in this context, with the increasing need of entrepreneurs, that this area is being a priority in many countries, including Brazil, given the need to solve the most diverse social, economic and technological problems that the country has (Dornelas, 2008).

This new approach to entrepreneurship is not limited to increasing the supply of consumer goods or services. New businesses arise from people's experiences and learning to solve a collective problem that directly affects the consumer society. Such a change, according to Rottenberg (2015), is a reflection of how the life context of an individual generates an entrepreneurial attitude, so that these conditions are important to see the world in a different way, standing out from others in attitudes that bet on opposite directions of the common gaze. In their totality, innovative businesses deliver values that until then was not known the importance of them, due to the questioning of the reality, the impacts caused by the exaggerated consumption, by a new posture and new lifestyles.

Complementing this idea, still, as a result of globalization and the rapid evolution of technologies, have led to a change in consumption behaviors and lifestyles. The excess of information has built a consumer market with several user profiles, which demands of the companies a greater approximation with the requests, desires and needs of the consuming public. In this way seemingly simple questions become more complex than previously imagined, decisions to produce, distribute, and consume represent complex systems of many elements, layers and structures, and intense and continuous redefinitions. As a consequence, addressing the current problems that affect the well-being of society requires a creative and innovative attitude, that is, entrepreneurs increasingly able to understand this context and materialize in solutions that are really relevant to society (Cardoso, 2012).

In the late 1990s, the term "entrepreneur" was not widespread and was not even used by the majority of people who started an enterprise. Entrepreneurship was an academic concept, but the term (or any similar term used to denote the same thing) was little known in most countries, the North Americans viewed entrepreneurship as a rather vague notion, applicable to the founders of faster-growing (or immediate-failing) firms (Rottemberg, 2015). At present, undertaking does not necessarily refer to the initiative of setting up a technology company.

It means to lead any initiative that has an impact, from the promotion of an improvement, the modernization of a family business to the presentation of new proposals within an or- 
ganization, closely linked to the solution of problems of a community. Entrepreneurship, defined as an agile, creatively disruptive force, has consolidated the technical dynamics of problem solving in the 21st century. The moment is conducive to entrepreneurs as a breaking power and agents of change for the world and organizations (Keeley, 2015).

The reasons that led to this change are complex, but point to an undeniable reality: there is a moment of uncertainty. Although controversial such a statement, it is perceived that there are no more savings, jobs, companies stable or guaranteed. The present world is driven by a single constant factor: change. In order to survive, differentiation requires skills to reinvent itself all the time, whether in the sphere of the individual or in organizations (Rottemberg, 2015).

In this way, entrepreneurs are also agents of innovation, individuals with excellent ideas, whose potential is to build enterprises that can make a difference in society, as well as serve as inspiration for other people, through the desire to take initiative and contribute to the progress and improvement of the quality of life of a country.

Startups have unique characteristics when compared to traditional micro and small enterprises. Its condition of existence is innovation, however, no matter how much a startup has a revolutionary idea, it is no guarantee of sustainable success. Since they are companies that take the risk of innovating from the conception of the business, they face very particular challenges. Ries (2012) argues that traditional methods of administration do not apply to startups, as these approaches are based on predictions that work best in static environments, to the detriment of the dynamic environments in which these firms are inserted, with frequent changes and risks.

To support the survival of startups-type business models, given their importance to an economy in 1959 in the United States, the first initiatives for the generation of innovative ventures emerged, which accompanied a business from its initial stage, as well as assisting in their development, from before the formalization and opening to market, so-called incubators.

Design is considered an important element in the universe of innovation and entrepreneurship, no longer restricted to the aesthetics of products, which also corresponds to an inappropriate discourse for such importance and relevance, which the area is in, but focuses on a process of ideation that aligns business needs such as strategies, creativity, resources, market demands and opportunities, to ensure user satisfaction, as well as the company's profitability (Kotler, 2011; Martins and Merino, 2011).

In this sense, the area of design management presents itself as a recent, current and appropriate approach to make startups companies agile and scalable. It is being disseminated in the management universe of organizations as a way to engage the people of the company in search of creating a truly considerable value offering since it helps to structure and design their environment to make it understandable. What started as a way of empowering creativity within organizations is gaining new horizons through different cognitive modes that apply in different contexts, from strategy to business integration (Liedtks\&Ogilvie, 2015; Mozota, 2011).

The design and management approach to design management allows managers to put tools and processes in place to promote innovation and growth (Liedtks\&Ogilvie, 2015). It is in this sense that the present research carried out an immersion in the triad-innovation, 
entrepreneurship and design management- and how this universe can be applied in startups companies, so that they can maintain their innovative competence over time, through the processes of design. In order to do so, it was necessary to deepen bibliographical and documentary, besides the application of interviews, to understand the management and the programs to foster innovative entrepreneurship, which provide subsidies for the problematic in question: How can design processes contribute to promote the development of innovative capacity in startup companies?

\section{Innovation: from the beginnings to the contemporary}

In the history of mankind there are records of discoveries that were consequences of a human need to survive a hostile and little-known environment. The bow and arrow, the fire, the wheel were the first records of the human capacity to innovate. Innovation is probably the oldest known process. In other words, innovation is an extension of the creativity of human beings. Man uses his abilities to create something new and to help the human species, being a transforming agent of his own reality (Gupta, 2012).

With the improvement of the techniques of producing and creating, together with a greater domination of man over nature, in the Middle Ages, artisans contributed to society by promoting significant changes in objects, including art and cultural values, as well as greater organization of work on developing products. There was a complete mastery of the process of producing, that is, who "projected" (conceived, created and developed) the artifact was also the same that executed, which, in turn, got the raw material and sold (Linden and Martins, 2012).

Already in the Renaissance period, a new way of producing and designing the products was sought, thanks to the evolution of science and engineering, which were responsible for new contributions to society. From the seventeenth century onwards, art gradually distanced itself from technique, work processes within the workshops already included more people involved, growing urban centers and an expanding consumer market, culminating the Industrial Revolution in the nineteenth century (Linden and Martins, 2012).

This period is considered an important milestone in the history of the world economy and is characterized by the emergence of innovations responsible for increasing industrial productivity and economic growth. This milestone is credited with the improvement of production techniques, due to a high growth consumer market. Producing more in less time was a rule that dictated the progress of that time. Thanks to the innovations of the period, such as steam engine and combustion engines, they allowed the origin of new markets, and consequently, the consumption form of society (Tigre, 2006).

Theorists Frederick W. Taylor and Henry Ford were responsible for the beginning of the studies of the Scientific Administration and introduced the concepts of planning, standardization, specialization, control and remuneration to assist the entrepreneurs to manage their businesses, in the face of the rapid changes that have occurred in the business environment of the period and that allowed the understanding of capitalism as a phenomenon (Chiavenato, 2002). 
Industrialization, characterized by Bonsiepe (2011, p. 23), was "an indispensable means to democratize consumption and to allow a broad segment of the population access to a universe of technical products to improve daily life" has its importance in different spheres of human life, whether in domestic tasks, health, education, leisure or even transportation. Besides its importance, industrialization was responsible for a growing consumer market, more demanding and eager for new products, in addition to this fact a high and fierce competition between companies. Joseph Schumpeter (1883-1950) defended the idea that companies needed to produce other things, or the same things in other ways, to combine different materials and forces, and to make new combinations (Schumpeter, 1997). This postulation was responsible for introducing the idea of the need for business innovation to boost an economy, for companies to differentiate themselves, to conquer new markets, and to meet growing demand.

Organizations, in turn, invested their resources in technological innovation to raise productivity, as well as the use of new materials that have improved product quality. However, since the 1990s, technological superiority or industrial performance maximization was no longer a strategy of innovation or elevation of competitiveness (Adler et al, 2012). Industrialization has generated a consumer society designed and designed for an economy in which resources would be infinite, unlike the real and present world, whose sources are exhaustible. Thus, technocentric vision has become less feasible by opening up new choices that result in differences with sense of purpose no longer as differentiating elements (Brown, 2010).

This brief historical context shows that the benefits that innovations have brought to the lives of people and society is unquestionable. Currently, there is no longer a need to innovate to survive in nature, however diseases such as diabetes, cancer, hypertension reach a significant portion of the world population, in this sense, studies and consequently the evolution in the treatment of such diseases require that innovations happen from the perspective of new purposes, that is, they are responsible for improving people's quality of life (Keeley,2015).

On the other hand, innovation has been highlighted as a major driving force for the sustainable growth of nations. The importance of the different dimensions of innovation in relation to economic growth and the generation of employment and income and increased competitiveness is undeniable, so many countries are investing increasing sums to develop the innovative potential of their companies, universities, cities, public services and patents.

\section{Aspects of Innovation and Design}

Innovation is a fundamental element in the construction of a new entrepreneurial mindset, which is not limited only to the product, but rather to the creative use of methods, processes and management tools that seek user satisfaction and organizational profitability, as well as unprecedented results and relevant to the consumer society (Martins and Merino, 2011).

In times of high competition and an increasingly demanding society -the result of numerous economic, social and environmental changes since the Industrial Revolution- have re- 
sulted in the importance of a strategic approach to innovation. According to Fraser (2013), if an excellent idea is not translated into a clear strategy to direct efforts and investments, whose focus is only on creative discovery, the materialization of innovation is unlikely. In this context, innovation should not be considered a random activity or a result of chance. Scherer and Carlomagno (2009) argue that although an idea may lead to innovation, a company cannot be dependent on this unexpected or unusual to develop its competitive capacity. The importance of understanding innovation as a process is that this vision changes the way it ceases to be an eventual activity to be managed on an ongoing basis. Continuously innovating -with positive results, relevant social impact and balancing opportunities and risks- is one of the great challenges of companies of all sectors and dimensions. The aim of this article, to present an extract about a broader research, is that of first acting in the themes of design, entrepreneurial innovation and entrepreneurship whose dissemination in the academic milieu is recent, since the presence of design as a participant element of the business management and innovation in business is still a new issue in Brazil. Therefore, the contribution of research on the subject is of great relevance for enabling clarification and help the implementation of instruments capable of putting into practice projects of products and services and generate innovation for the country.

Second, startups are considered fragile companies in Brazil. One reason that leads to high failure rates can be justified by the lack of adherence of their products or services to the consumer market due to their limited ability to understand the environment in which they operate (Xavierr and Cancellier, 2008).

This reality reinforces the importance of the development of research oriented to better understand the context of startups. The concepts currently used to deal with management in these companies are scarce and require adaptations to a new entrepreneurial reality in Brazil. From a financial volume point of view, the impact of these companies on the economy is still small, however startups stand out for providing solutions that are based not only on high technology but also on social impact or service delivery. As an example, the Brazilian company Easy Taxi, which has developed an innovative mobile application for the public to receive taxi services in a safe and extremely fast, quality service, minimizing the negative impacts of an extremely problematic transportation network in the country.

Innovation is the key word of the current economic, social and cultural scenario of our country.

The importance of development is crucial for job creation, income and infrastructure. Moreover, it is a matter of progress of a country. There is also a high gap between the generation of knowledge and the materialization of innovation, so investments in policies to stimulate and practice the innovation of products and services in Brazil become extremely important. In this context, the present research project becomes important, as it will be applied in the Digital Port. This Pole is part of the strategies of innovation promotion of the government of the state of Pernambuco. It is also considered one of the pillars of the economy that employs more than 6,500 people in its nearly 200 participating companies. Porto Digital became recognized in the country for cases of successful innovation, even compared to the American model, the well-known Silicon Valley.

In this way, the present study becomes relevant, since it will deal with peculiar traits and still little explored in the context of such companies from the point of view of design, 
entrepreneurship and innovation, that require studies and specific reflections capable of potentializing and developing the performance of these enterprises and, consequently, to promote a sustainable and sustainable path, essential for the country's development.

\section{Startups and their Sustainable Principles}

It is common to associate startup companies with organizations that produce cuttingedge technology. In spite of this conception, nowadays, its definition is much broader. The "boom" of companies of this size happened in the 1990s, thanks to the progress of Information Technology (ICT). This period, also characterized by globalization, the large territorial expansions of corporations around the world, as well as the advances of bureaucratic hierarchies, of excessive organizational planning, which sought to mitigate business risks, startups gained strength sailing in the opposite direction of these organizations (Thiel, 2014). Blank and Dorf (2012) argue that a startup company, tied to any type of business that is not focused on product or service innovation and therefore exempt from uncertainty, is not a startup. They operate based on the principle of interaction with other people, are small in resources and motivated to build a different future through new positions and ideas.

This new identity is due to the fact that very young companies have reached the level of valuable, traditional and time-consuming organizations in the market. Previously, this lack of experience and wisdom would have kept most of these startups from any chance of success. This, however, does not happen anymore. One of the most important characteristics of these organizations is the rapid growth, in which the speed at which they stand out surpasses the traditional, dense and slow organizations (Butler \& Tischler, 2015).

It is important to emphasize that, at the turn of the third millennium, still under the influence of the rapid evolution of ICT, many startups companies became known as dotcom. In general, they were ambitious and creative, offered high risks, distinguished from large corporations because they were not conventional, but used traditional management methods as well as large companies. Despite the high investment values, many of them lived intensely, but young people died (Butler \& Tischler, 2015).

That was the case with Webvan. When the dot-com bubble was inflated to its fullest, this startup was highlighted with a bold idea of reaching virtually every American household through an online retail platform that marketed food products, low-margin business, and fierce competition (Blank \& Dorf, 2012), the company was aiming to revolutionize the retail market for groceries for door-to-door delivery on the same day.

In spite of the high investment, as well as decisions always in convergence with the Board of Directors, in addition to being a pioneer in this type of business, in only 24 months, Webvan broke, contradicting all the way planned for the success of this organization. They adopted the methodology of product development, launch and life cycle management in a manner similar to the processes taught in business schools and used in successful companies. A true instrument of goal verification and control with steady steps in obtaining an ideal product, yet with so much care in the perfect management of the organization, it was yet another case for the cruel statistics in the world of American startups: nine out of ten products fail (Blank \& Dorf, 2012). 
The experiences of this period contributed to the learning about startups, their products, as well as their business model. It is not clear to what extent Webvan's entrepreneurs failed, but the fact of online purchase of this type of product was not an unmet need of customers, but a repetitive business model that did not delight consumers (Butler \& Tischler , 2015). It is in this context that startups could no longer be defined by their state-of-the-art technology as well as their management methods follow models that are applied in large organizations. In this sense, according to Butler \& Tischler (2012), a startup is not the smaller version of large companies, or even small models of small organizations. It can be defined as a temporary organization designed to pursue repeatable, scalable, and profitable business models. Expanding this definition, Ries (2012, p. 24) conceptualizes a startup as

A company or a human institution that is built in the most diverse branches and that spontaneously emerges the condition of extreme uncertainty, has in its essence the innovation to create products and services that intend to revolutionize the market.

Nowadays, the consumer environment is characterized by its high competitiveness, startup companies play an important role. Young entrepreneurs willing to take risks, with disruptive ideas and a lot of creativity, create completely new businesses that help reinvigorate a country's economy. However, it is perceived that the fact that a startup has a revolutionary idea is not a guarantee of sustainable success. Generally, these companies are seeking financing to make their projects scalable and profitable.

As the startup market is characterized by uncertainty and also because they are completely new companies, there is no long and stable operating history, since they do not have statistics or experience, which makes them companies with a high mortality risk in the first years of activity. The great challenge of these companies is to remain essentially creative not only in product or service innovation, but also in the company's management mechanisms.

It is with this thought that other business functions also become as important as the development of new products or technologies. A startup should not focus on the product only, but on its market, competitors, users, suppliers to identify real opportunities for innovation. To do so, it is important to have a long-term strategic vision, with objectives and goals set for young entrepreneurs to have an instrument to guide their actions.

This movement was an important milestone, since it gave rise to the first startups in Brazil. The scenario of these companies in the country is still incipient and lack studies that point out the current reality of these organizations in the country. It is estimated that the mortality of these organizations is high, about $50 \%$ do not survive the first four years of operation. There are around 10 thousand startups that in 2012 totaled about $\mathrm{R} \$ 2$ billion, which represents $0.4 \%$ of the Brazilian GDP. It argues that traditional management methods do not apply to startups, since these approaches are based on predictions that work best in static environments, to the detriment of the dynamic environments in which those enterprises are incorporated, with frequent changes and risks. In this sense, the area of design management presents itself as a recent, current and appropriate approach to make start-up companies agile and scalable. It is being unveiled in the organization manage- 
ment universe as a way to engage the people of the company in search of creating a truly considerable value offering as it helps to structure and design your environment to make it understandable.

What started as a way of empowering creativity within organizations is gaining new horizons through different cognitive modes that apply in different contexts, from strategy to business integration.

In this way, it was possible to emerge, through this research, on the procedural design practice, the performance in the important dimensions of an initialization and its methods.

\section{Conclusion}

By applying this research, we formulated a kind of global thinking of what many startups can make use of in the future for better performance, observing design as an important strategy, presenting the five design processes that were thought of:

1. In the creation of the strategic plan of an initialization, fundamental for the understanding of the opportunities in the market, in the definitions and organizational objectives and in the definition of the work teams.

2. The ability to generate ideas, a process that encourages the whole company to propose new possibilities, opportunities, using creative processes to use in favor of their products, services and experiences.

3. When creating concepts, the process that aims to create new meanings, forms of use, payment models, that stimulate the company to focus on radical innovations.

4. In relation to the company, the way customers see the brand, the values, the products and services and perceive the corporate values at the time of consumption.

5. In the integration of design to ensure superior quality, hence the success of innovation.

\section{References}

Blank, S. e Dorf, B. (2014). Startup: Manual do Empreendedor. São Paulo: Alta Books. Bonsiepe, G. (2015). Do material ao digital. São Paulo: Blucher. . (2011). Design, Cultura e Sociedade. São Paulo: Blucher.

Brown, T. (2010). Design Thinking: Uma metodologia poderosa para decretar o fim das velhas ideias. Rio de Janeiro: Elsevier.

Butler, D.; Tischler, L. (2015). Design para crescer: Aprenda com a coca cola sobre escala e agilidade. 1 ed. Rio de Janeiro: Elsevier.

Cardoso, R. (2012). Design para um mundo complexo. São Paulo: Cosac Naify.

Chiavenato, I. (2003). Introdução Geral da Administração. Rio de Janeiro: Elsevier.

Dornelas, J. (2016). Empreendedorismo: Transformando ideias em negócios. 6 ed. São Paulo: Empreende/Atlas.

Fundação Dom Cabral, Causas da mortalidade em startups brasileiras: O que fazer para aumentar as chances de sobrevivência no mercado? Disponível em: https://www.fdc.org. 
br/blogespacodialogo/Documents/2014/causas_mortalidade_startups_brasileiras.pdf. Acesso em: 25 abr. 2016.

Gupta, P. (2012). Inovação Empresarial no séc. XXI. São Paulo: Vida Econômica Editorial.

Kelley, T. (2007). As 10 faces da inovação: estratégias para turbinar a criatividade. Rio de Janeiro: Elsevier.

Liedtka, J.; Ogilvie, T. (2015). A magia do design thinking: um kit de ferramentas para o crescimento rápido da sua empresa. São Paulo: HSM Editora.

Martins, R. F. F; Merino, A. D. (2011). A gestão de Design como estratégia organizacional. 2 Ed. Londrina: Eduel; Rio de Janeiro: Rio Books.

Moraes, D. de. (2006). Análise do design brasileiro entre mimese e mestiçagem. São Paulo: Blucher.

Mozota, B. B. de. (2011). Gestão do design: usando o design para construir valor de marca e inovação corporativa. Porto Alegre: Bookman.

Pinheiro, T. (2015). The service Startup: inovação e empreendedorismo por meio do design. Rio de Janeiro: Alta books.

Ries, E. A. (2012). Startup Enxuta: Como Os Empreendedores atuais utilizam a Inovação Contínua para criar empresas extremamente bem sucedidas. São Paulo: Leya.

Rottenberg, L. (2015). De empreendedor e louco todo mundo tem um pouco: Perder o juízo pode ser um bom caminho. São Paulo: HSM Editora.

Schumpeter, J. (1947). The Criative Response in Economic History: The Journal of Economic History. Inglaterra: Cambridge University Press.

Thiel, P. (2014). De zero a um: O que aprender sobre empreendedorismo com o Vale do Silício. 1 ed. Rio de Janeiro: Objetiva.

Tigre, P. B. (2006). Gestão da Inovação: A economia da Tecnologia no Brasil. 2 ed., Rio de Janeiro: Elserve.

Resumen: La innovación ha sido una palabra importante en los negocios en los últimos años. Asociado con una serie de modelos comerciales altamente rentables, ofrece a los empresarios un desafío que va más allá de la definición de "promover algo nuevo". La innovación continua, con resultados positivos, impacto social relevante y oportunidades y equilibrando los riesgos, es uno de los grandes desafíos de todos los sectores y dimensiones. Alentados por muchos ejemplos del éxito estadounidense, la globalización y la pos-industrialización, muchos jóvenes se aventuraron en el mundo de los negocios, desarrollando contenido basado en la tecnología. Las startups son uno de estos modelos, ya que tienen características únicas en comparación con las micro y pequeñas empresas tradicionales. Su condición de existencia es la innovación, sin embargo, por mucho que una startup tenga una idea revolucionaria, no es garantía de éxito sustentable.

Palabras clave: Innovación - emprendimiento - gestión del diseño - startups - diseño.

Resumo: A inovação é uma palavra importante para os negócios atuais. Associado como uma série de modelos comerciais altamente rentáveis oferece aos empresários um desafio 
que vá além da definição de promover algo novo. A inovação constante, com resultados positivos, impacto social relevante e oportunidades e equilibrando os riscos, é um dos grandes desafios de todos os setores e dimensões. Alentados por exemplos exitosos nos EEUU, a globalização e a pós - industrialização, muitos jovens ingressaram no mundo dos negócios, desenvolvendo conteúdos baseados na tecnologia. As startups são um destes modelos, já que tem características únicas em comparação com as micro e medianas empresas tradicionais. Sua condição de existência é a inovação, enquanto por muito que uma startup possua uma ideia revolucionaria, não é garantia de êxito sustentável.

Palavras chave: inovação - empreendimento - gestão do design - startups - design. 